\title{
Research on the relationship between Internal Governance Mechanism, Corporate Social Responsibility and Corporate Value in Food Industry
}

\author{
Meng Liu ${ }^{1, a}$, Wenlin $\mathrm{Gu}^{2, \mathrm{~b}}$ \\ ${ }^{1}$ Business College, Hohai University,No.8 Focheng West Road,Jangling, Nanjing, Jiangsu Province, \\ China \\ ${ }^{2}$ Business College, Hohai University,No.8 Focheng West Road,Jangling, Nanjing, Jiangsu Province, \\ China \\ amm656893@163.com, ${ }^{\text {b } 564969917 @ q q . c o m ~}$
}

\begin{abstract}
Keywords: Internal governance mechanism, corporate social responsibility, corporate value
Abstract. Based on the data of food industry in China during the year 2010 to 2014, this paper empirically analyzes the impact of internal governance mechanism, corporate social responsibility on corporate value. The results show that the proportion of the first major shareholders, consumer social responsibility, corporate social responsibility and government social responsibility are significantly positive correlated with the value of the enterprise; the proportion of executives holding shares and the social responsibility of creditors are significantly negative correlated with the value of the enterprise. On this basis, policy suggestions are put forward to guiding enterprises to better realize corporate value.
\end{abstract}

\section{Introduction}

Under the background of China's economic development in new normal, the food industry got rapid development as one of the most important support of national economy. With the improved consumer awareness to safeguard their own legitimate rights and interests, much higher requirements about food quality are put forward, which makes food safety issues become social focus and more sensitive than before. In recent years, a series of food safety incident have been frequently exposed, casting a shadow to food industry. Adverse consequences made industry's reputation plummeted and seriously hindered the healthy development of the industry. Corporate social responsibility (CSR) is the only way that can help food enterprises transform the crisis and thus the entire food industry can return to the benign development track. Having a direct bearing on the people's life safety and national stability, food enterprises must attach great importance to and conscientiously fulfill their social responsibilities while seeking steady growth of benefits. The decision to fulfill CSR is greatly related to corporate internal governance mechanism. Hence, this paper are going to study on relations between internal governance mechanism, corporate social responsibility and corporate value in food industry and provide evidence support and suggestions for food enterprises.

\section{Literature Review}

The relationship between Internal governance mechanism and corporate value. Sun and Zhang took 519 listing companies in A-share market as research sample and confirmed that the size of the board of directors of China's Listed Firms was negatively correlated with corporate value, the smaller the size of the board of directors, the more business value creation ${ }^{[1]}$. Zhou and Hao analyzed 509 sample companies, and considered that the impact of the board of directors on corporate value was negative in the short term, but from long-term consideration the influence would be positive ${ }^{[2]}$. Tan and Jing found that corporate value and the first major shareholder's shareholding were in significantly positive U-shaped relationship, and the balance of ownership had a significant negative correlation with corporate value ${ }^{[3]}$.The relationship between CSR and corporate value. Wang et al. used method of Game Analysis and confirmed that in the same industry, large enterprises in dominant position undertaking CSR could realize far greater enterprise value than the cost of CSR, in contrast, 
small and medium enterprises without CSR could get far greater than prospective earnings by assuming $\mathrm{CSR}^{[4]}$. Wang found that in the dairy industry, the contribution rate of enterprises to the creditors and the contribution rate of shareholders both had significantly positive correlation with corporate value $^{[5]}$. Kong and $\mathrm{Li}$ tested the relationship between CSR and corporate financial performance, and found that the good social responsibility performance could effectively improve the financial performance of enterprises ${ }^{[6]}$. Therefore the research hypothesis of this paper are proposed as follows:

H1: Good corporate governance mechanism has a positive effect on corporate value.

H2: Positive behavior of assuming CSR can help improve the creation of corporate value.

\section{Materials and Methods}

In this paper, we select 47 companies listed in the Shanghai and Shenzhen Stock Exchange of our country, a total of 231 data samples of food industry during the year 2010 to 2014 are chosen as initial sample. To make the data representative, taking into account that the performance of new listed companies is not stable enough, we exclude the newly-listed companies in or after 2009. To ensure the quality of statistical data, we exclude companies that ST, * ST or PT; To avoid the influence of different regulatory environment on the internal governance, we also exclude listed companies who issued B shares and $\mathrm{H}$ shares; To eliminate the effect of outliers, we exclude listed companies whose total assets, liabilities, net assets book value index is negative or for 0 . All data source from database called CSMAR, data processing by SPSS20.0, Excel2007.

Corporate value index. We select Earnings Per Share (EPS) as variable to measure enterprise value. EPS can effectively reflect after-tax profits created by per share, the higher the ratio, the more profits companies create.

Internal governance mechanism. The main effect factors of internal corporate governance mechanism are the following six indicators: the proportion of the largest shareholders, ownership balance, chairman and general manager of two jobs is divided, executives' shareholding, director size and the proportion of independent directors.

Corporate social responsibility index. According to the definition of corporate social responsibility, this paper evaluates CSR from the following six aspects: enterprise's responsibility for consumer, for staff, for creditors, for community, for community and for government. Specifically, $\mathrm{CSR}=$ current business income + cash paid to employee and for employee + cash paid for goods purchased and labor services received + cash paid for distribution of dividends, profit or cash payments for interests + expenditures for public welfare donations + taxes paid. Taking into account those six aspects of different contribution rate to corporate social responsibility, we add weight to evaluate CSR. Take consumer responsibility for example, the revised contribution rate of corporate social responsibility can be calculated as: consumer responsibility contribution rate $=$ current operating income * current operating income / corporate social responsibility / total assets of the company. To avoid repetition, formula of the other five indicators' rate of contribution will not described in this paper.

Control variable. The size of the company, growth and capital structure are chosen as control variables in this paper to help empirical analysis. The specific definitions of the variables are shown in 
Table 1:

Table1 Summary and definition of variables

\begin{tabular}{ccc}
\hline Variable classification & Variable name & Variable symbol \\
\hline Dependent variable & Corporate value & EPS \\
\hline & Largest shareholder stake & $\mathrm{CR}$ \\
Enternal governance & Equity balance degree & $\mathrm{Z}$ \\
mechanism & If Chairman and general manager set respectively & Twop \\
& Proportion of top executives & TMS \\
& Board size & BS \\
& Independent director ratio & BI \\
\hline Corporate social & Consumer responsibility & Cusr \\
responsibility & Employee responsibility & Empr \\
& Creditor responsibility & Crer \\
& Shareholder liability & Shar \\
Control variable & Community responsibility & Comr \\
& Government responsibility & Govr \\
\hline & Firm size & Size \\
\hline
\end{tabular}

Model construction. Based on the analysis of the impact of corporate internal governance mechanism, corporate social responsibility on corporate value, using multiple linear regression analysis method to test the research hypotheses, the model is constructed as follows:

$\mathrm{EPS}=\beta_{0}+\beta_{1} \mathrm{CR}_{\mathrm{i}}+\beta_{2} \mathrm{Z}_{\mathrm{i}}+\beta_{3} \mathrm{Twop}_{\mathrm{i}}+\beta_{4} \mathrm{TMS}_{\mathrm{i}}+\beta_{5} \mathrm{BS}_{\mathrm{i}}+\beta_{6} \mathrm{BI}_{\mathrm{i}}+\beta{ }_{7} \mathrm{Cusr}_{\mathrm{i}}+\beta_{8} \mathrm{Empr}_{\mathrm{i}}+\beta_{9} \mathrm{Crer}_{\mathrm{i}}+\beta_{10}$ Shar $_{\mathrm{i}}$ $+\beta_{11} \mathrm{Comr}_{\mathrm{i}}+\beta_{12} \mathrm{Govr}_{\mathrm{i}}+\beta_{13} \mathrm{Size}_{\mathrm{i}}+\beta_{14} \mathrm{Grow}_{\mathrm{i}}+\beta_{15} \mathrm{DAR}_{\mathrm{i}}+\varepsilon_{\mathrm{i}}$

Among them, $\beta_{0}$ is intercept, $\beta_{1-} \beta_{15}$ are coefficient, $\varepsilon_{i}$ is residual epsilon.

\section{Results and Discussion}

Descriptive statistics of variables. From table 2 , the results show that the maximum value of EPS is 15.378 , the minimum value is -1.1528 , the mean value is $0.631, \mathrm{Z}$ minimum 0.580 , maximum 40.441 , the standard deviation up to 6.415 , which reflects the large gap between the company's value and the overall level is low. The differences may be caused by the different nature of equity and so on; the value of Twop is 0.9, the standard deviation is 0.296 , showing that in order to achieve the right balance, the vast majority of the companies make the two positions of general manager and chairman in separation; executives shareholding is low as a whole, because executives incentives for executives on corporate governance has not been universally implemented in China; the scale of the board of directors of the listed companies generally maintained at about 8 people, the independent directors of the ratio of the maximum $66.7 \%$, minimum 0 , average $37.2 \%$, indicating that proportion of independent directors in many companies has over $1 / 3$ of the total number of the board size. 
Table 2 Descriptive statistics of variables

\begin{tabular}{cccccc}
\hline Variable classification & Variable name & Min & Max & Mean & Standard deviation \\
\hline Corporate value & EPS & -1.152 & 15.378 & 0.631 & 1.828 \\
\hline & CR & 0.000 & 1.000 & 0.240 & 0.430 \\
Internal governance & Z & 0.580 & 40.441 & 6.213 & 6.415 \\
mechanism & Twop & 0.000 & 1.000 & 0.900 & 0.296 \\
& TMS & 0.000 & 0.055 & 0.001 & 0.007 \\
& BS & 0.000 & 15.000 & 8.890 & 1.886 \\
& BI & 0.000 & 0.667 & 0.372 & 0.084 \\
\hline \multirow{5}{*}{ Corporate social } & Cusr & 0.026 & 2.637 & 0.459 & 0.361 \\
responsibility & Empr & 0.000 & 0.019 & 0.004 & 0.003 \\
& Crer & 0.002 & 2.656 & 0.298 & 0.380 \\
& Shar & 0.000 & 0.024 & 0.001 & 0.003 \\
& Comr & 0.000 & 0.002 & 0.000 & 0.000 \\
Control variable & Govr & 0.000 & 0.103 & 0.011 & 0.016 \\
& Size & 20.102 & 24.911 & 21.939 & 1.026 \\
& Grow & -1.000 & 1.000 & 0.040 & 0.243 \\
\hline
\end{tabular}

Correlation analysis. Table 3 gives the Pearson correlation analysis between the variables. CR and BS have a significant positive correlation with EPS, revealing that the internal governance mechanism of the company has a significant impact on corporate value, which makes further testing of Hypothesis 1 possible. Shar and Govr both have a significantly positive correlation with EPS, showing that CSR has a significant impact on the value of the enterprise. The analysis above puts further validation of Hypothesis 2 that CSR have a positive role in promoting the value of the enterprise. The correlation coefficient between the explanatory variables is not more than 0.5 , the highest of the correlation coefficient between Shar and EPS is 0.505. We can conclude that there is almost no linear problem between the 12 explanatory variables.

Table 3 Pearson correlation matrix of the variables

\begin{tabular}{lccccccccccc}
\hline Variable & EPS & CR & Z & Twop & TMS & BS & BI & Cusr & Empr & Crer & Shar \\
\hline CR & $.254^{* * *}$ & & & & & & & & & & \\
Z & .052 & $.444^{* * * *}$ & & & & & & & & & \\
Twop & .070 & .117 & -.015 & & & & & & & & \\
TMS & -.057 & -.080 & -.087 & .056 & & & & & & & \\
BS & $.180^{* * * *}$ & .116 & -.067 & -.036 & -.004 & & & & & & \\
BI & .058 & .096 & .054 & -.100 & -.007 & .042 & & & & & \\
Cusr & .032 & .129 & .008 & $.231^{* * *}$ & -.040 & $-.219^{* * *}$ & .066 & & & \\
Empr & -.079 & $.132^{* *}$ & $.160^{* *}$ & .048 & $-.172^{* * *}$ & .055 & .006 & -.101 & & & \\
Crer & -.062 & .058 & -.005 & $.171^{* * *}$ & .016 & $-.247^{* * *}$ & .004 & $.923^{* * *}$ & $-.219^{* * *}$ & & \\
Shar & $.505^{* * * *}$ & .065 & -.023 & .105 & .026 & $.175^{* * *}$ & .049 & -.105 & -.103 & $-.198^{* * *}$ & \\
Comr & -.036 & -.033 & -.041 & .025 & -.014 & .006 & -.033 & -.062 & .019 & -.056 & -.029 \\
Govr & $.473^{* * *}$ & $.257^{* * *}$ & $.227^{* * *}$ & .106 & -.094 & $.172^{* * *}$ & .030 & $-.139^{* *}$ & $.199^{* * *}$ & $-.361^{* * *}$ & $.429^{* * *}$ \\
\hline
\end{tabular}

OLS multivariate regression analysis. According to the established model1-model4 in table 4, the fractional step method of OLS Regression is used to analyze the company's internal governance mechanism, corporate social responsibility and corporate value. The results show that, compared with model1-model3, model 4 has a higher fitting degree with the $\mathrm{R}^{2}$ Adjusted value is $44.1 \%$. Through the analysis of model4, we can see that CR, Shar, Govr and Size, these four variables are significantly 
positively correlated with EPS; TMS and DAR are in significantly negative correlation with EPS; and the other variables have no significant effect on corporate value. In order to carry out different variance test for the regression result in model 4, the residual absolute value of $|\mathrm{e}|$ and the independent variables are analyzed by the method of Spearman Correlation Analysis. Taking 1/|e| as the weight of model4, we can get the final test model5 in table4.

Table 4 OLS regression and WLS improved results

\begin{tabular}{|c|c|c|c|c|c|}
\hline $\begin{array}{c}\text { Independent } \\
\text { variable }\end{array}$ & Model 1 & Model 2 & Model 3 & Model 4 & $\begin{array}{l}\text { WLS improved } \\
\text { Model } 5\end{array}$ \\
\hline Intercept & $-26.242^{* * * *}$ & -43.330 & -62.845 & $-13.102^{* * * *}$ & $-6.963^{* * * *}$ \\
\hline CR & & -19.468 & & $0.471^{*}$ & -0.127 \\
\hline $\mathrm{Z}$ & & 1.352 & & -0.010 & $-0.020^{*}$ \\
\hline Twop & & 19.955 & & -0.047 & 0.034 \\
\hline TMS & & -1146.992 & & $-25.461^{*}$ & $-20.711^{* *}$ \\
\hline $\mathrm{BS}$ & & 0.310 & & -0.051 & -0.043 \\
\hline BI & & 87.263 & & -0.958 & 0.908 \\
\hline Cusr & & & -20.157 & -0.302 & $2.216^{* * *}$ \\
\hline Empr & & & 1938.238 & -34.169 & -35.048 \\
\hline Crer & & & 25.796 & 0.496 & $-1.826^{* *}$ \\
\hline Shar & & & 101.611 & $158.500^{* * * *}$ & $74.383^{* *}$ \\
\hline Comr & & & 16800.442 & -108.789 & 6381.729 \\
\hline Govr & & & -146.909 & $28.508^{* * *}$ & 7.635 \\
\hline Size & $1.265^{* * *}$ & -0.552 & 2.680 & $0.653^{* * *}$ & $0.329^{* * *}$ \\
\hline Grow & 1.299 & 3.455 & 7.253 & 0.400 & 0.179 \\
\hline DAR & $-2.790^{* * *}$ & -8.145 & -1.996 & $-0.505^{* *}$ & -0.231 \\
\hline F-measure & $25.588^{* * *}$ & 0.187 & 0.510 & $12.926^{* * *}$ & 7.213 \\
\hline Adjusted $\mathrm{R}^{2}$ & 0.245 & -0.033 & -0.020 & 0.441 & 0.498 \\
\hline
\end{tabular}

Note: $* * *, * * *$ respectively represents the significant level of $10 \%, 5 \%, 1 \%$

Modified WLS regression analysis. In mode15, CR has a significant positive correlation with EPS in a certain range and excessively large proportion will have negative impact on corporate value, which is consistent with the actual development of food companies. Z shows a significant negative correlation with corporate value and further demonstrates that high proportion of the first shareholder will create a negative phenomenon of "one share jumbo", hindering supervision mechanism playing a role. TMS and EPS are in a significant negative correlation, this is because when the executives stake beyond a certain range, they will have greater control and weak supervision over the company, offsetting the executives' shareholding incentive effects. The analysis above makes the hypothesis 1 that the good internal governance mechanism is conducive to the realization of the enterprise value verified eventually. Cusr, Shar, Govr and EPS are significantly positive related, which means that positive behaviors of companies assuming social responsibility can help get social recognition, so as to enhance corporate value. The correlation between Crer and EPS is significantly negative. Without affecting the premise of enterprise credibility, the behavior of assuming more responsibility for creditors will weaken the effect of accounts receivable as "virtual asset", causing negative impact to company's financial management to a certain degree.

\section{Conclusions}

In this research, the relationship between internal governance mechanism, corporate social responsibility and corporate value is empirically analyzed. The results show that the first major shareholder, consumer social responsibility, shareholder social responsibility and government social responsibility are in significantly positive correlation with corporate value; the balance of equity, share proportion held by management and the creditor social responsibility are significantly negative correlated with corporate value. Therefore, good corporate internal governance mechanism and active 
behavior of assuming CSR are both helpful to the realization of enterprise value. Because of the importance and particularity of the industry, listed companies in the food industry should establish and improve more reasonable internal control mechanism, strengthen CSR and fulfill supervision system, thus achieving sustained, healthy, stable and rapid development.

\section{Acknowledgements}

This work was financially supported by the Shanghai Natural Science Foundation (0666666), Innovation Program of Shanghai Municipal Education Commission (060000) and Shanghai Leading Academic Discipline Project of Shanghai Municipal Education Commission (0555555).

\section{References}

[1] Sun, Y.X., and R. Zhang: Board of directors, corporate governance and performance. Enterprise. Econ. Vol. 10 (2000), p. 13-15

[2] Zhou, Y.X. and Y.H. Hao: The structure of the board of directors, corporate governance and performance-based on the empirical data from the perspective of dynamic endogenous. Chin. Ind. Econ. Vol. 5(2010), p. 110-120

[3] Tan, Q.M., and M.Y. Jing: The internal governance mechanism and enterprise performance of management rights: empirical analysis based on panel data of Chinese listing Corporation. J. Harbin. Ind. Technol. Vol. 15 (2013), p. 66-74

[4] Wang, Z.J. and X.X. Wang: Analysis of the relationship between corporate social responsibility and corporate performance. Econ. Sur. Vol. 4 (2009), p. 101-105

[5] Wang, H.Y: Empirical analysis of the relationship between corporate social responsibility and financial performance: evidence from the listing Corporation in the dairy industry. Productivity. Res. Vol. 8 (2013), p. 181-183

[6] Kong, L. and R. Li: Research on the relationship between political connection, corporate financial performance and corporate social responsibility: a case study of Chinese food and beverage industry. J. Beijing. Jiaotong. Univ. Vol. 14 (2015), p. 53-61 